\title{
Evaluation of BDNF levels in patients hospitalized for physical trauma at an emergency hospital in Porto Alegre, southern Brazil
}

\author{
Avaliação dos níveis de BDNF em pacientes hospitalizados por trauma físico em \\ um hospital de emergência de Porto Alegre, sul do Brasil
}

Cleonice Zatti, ${ }^{1}$ (D) Luciano Santos Pinto Guimarães, ${ }^{2}$ (D) Márcia Rosane Moreira Santana, ${ }^{1}$

Eliana Ferreira Gonçalves Scherner, ${ }^{3}$ Emílio Salle, ${ }^{3}$ Renato Piltcher, ${ }^{3}$ Mariana Lunardi Spader, ${ }^{2}$

Vitor Crestani Calegaro, ${ }^{1}$ Bianca Wollenhaupt-Aguiar, ${ }^{4}$ Lúcia Helena Machado Freitas ${ }^{1,5}$

\begin{abstract}
Objective: To assess the association between brain-derived neurotrophic factor (BDNF) levels and acute stress disorder (ASD) in patients who have suffered physical trauma.

Methods: Data were collected at an emergency hospital in Porto Alegre, state of Rio Grande do Sul, southern Brazil. Participants were over 18 years of age, victims of physical trauma, and had been hospitalized for a minimum of 48 hours. A total of 117 hospitalized patients who agreed to participate in the research were grouped according to the shift in which blood was collected (38 subjects from the morning shift and 79 from the afternoon shift), had their BDNF levels measured and responded to other questionnaires. Respondents were further grouped by age into three ranges: $18-30,31-50$ and $51-70$ years.

Results: We found a significant difference in the distribution of BDNF between the two shifts in which blood samples were collected, with the afternoon group having higher BDNF levels $(U=1906.5, p=0.018)$. A difference was observed only between the 18-30 group and the 51-70 group in the afternoon shift $\left(U_{\text {morning }}=1107, \mathrm{p}_{\text {morning }}=0.575 ; U_{\text {afternoon }}=7175, \mathrm{p}_{\text {afternoon }}=\right.$ 0.028).

Conclusions: The population whose blood samples were collected in the afternoon showed significantly higher values of BDNF compared to those of the morning shift. This same population presented lower BDNF levels when associated with ASD subtypes $A 1, A 2$, and $A$. We hypothesize that the lower values of BDNF measured in the morning shift were due to a response to the circadian cycle of cortisol, whose action inhibits the expression of serum neurotrophins.
\end{abstract}

Keywords: Acute stress disorder, BDNF, physical trauma, trauma in childhood.

\section{Resumo}

Objetivo: Verificar a associação entre os níveis de fator neurotrófico derivado do cérebro (brain-derived neurotrophic factor [BDNF]) e transtorno de estresse agudo (TEA) em pacientes que sofreram trauma físico.

Métodos: Os dados foram coletados em um hospital de emergência de Porto Alegre, Rio Grande do Sul, Brasil. Os participantes eram maiores de 18 anos, vítimas de trauma físico e estavam hospitalizados por um período mínimo de 48 horas. Um total de 117 pacientes hospitalizados que concordaram em participar da pesquisa foram agrupados de acordo com o turno de realização da coleta de sangue (38 sujeitos no turno da manhã e 79 sujeitos no turno da tarde), tiveram seus níveis de BDNF medidos e responderam a outros questionários. Os entrevistados também foram agrupados por idade em três faixas etárias: $18-30,31-50$ e 51-70 anos.

Resultados: Encontramos uma diferença significativa na distribuição de BDNF entre os turnos, sendo que o grupo da tarde apresentou níveis maiores de BDNF $(U=1906,5, p=0,018)$. Houve diferença entre o grupo de 18-30 anos e o de 51-70 anos no turno da tarde $\left(U_{\text {manhã }}=1107, p_{\text {manhã }}=0,575 ; U_{\text {tarde }}=7175\right.$, $\left.\mathrm{p}_{\text {tarde }}=0,028\right)$.

Conclusões: A população cuja coleta ocorreu à tarde apresentou valores significativamente maiores de BDNF em relação à coleta do turno da manhã. Esta mesma população apresentou menores níveis dessa neurotrofina quando associada com os subtipos $A 1$, A2 e A de TEA. E possível hipotetizar que os menores valores de BDNF aferidos na coleta do turno da manhã se devam a uma resposta ao ciclo circadiano do cortisol, cuja ação inibe a expressão de neurotrofinas séricas.

Descritores: Transtorno de estresse agudo, BDNF, trauma físico, trauma na infância.

\footnotetext{
${ }_{1}^{1}$ Programa de Pós-Graduação em Psiquiatria e Ciências do Comportamento, Universidade Federal do Rio Grande do Sul (UFRGS), Porto Alegre, RS, Brazil. 2 Hospital de Clínicas de Porto Alegre (HCPA), Porto Alegre, RS, Brazil. ${ }^{3}$ Serviço de Saúde Mental, Hospital de Pronto Socorro de Porto Alegre, Porto Alegre, RS, Brazil. ${ }^{4}$ Department of Psychiatry and Behavioural Neurosciences, McMaster University, Hamilton, ON, Canada. ${ }^{5}$ Departamento de Psiquiatria e Medicina Legal, Faculdade de Medicina, UFRGS, Porto Alegre, RS, Brazil.

Submitted Jul 17 2018, accepted for publication Dec 102018.

Suggested citation: Zatti C, Guimarães LSP, Santana MRM, Scherner EFG, Salle E, Piltcher R, et al. Evaluation of BDNF levels in patients hospitalized for physical trauma at an emergency hospital in Porto Alegre, southern Brazil. Trends Psychiatry Psychother. 2019;41(3):237-246. http://dx.doi.org/10.1590/2237$6089-2018-0060$
} 


\section{Introduction}

Acute stress disorder (ASD) is a diagnosis organized under disorders related to trauma and stressors introduced in the Diagnostic and Statistical Manual of Mental Disorders, 4th edition (DSM-IV). Since then, a series of works have attempted to evaluate to what extent ASD might be a predictor of posttraumatic stress disorder (PTSD). ${ }^{1}$ However, the centrality defined by the DSM-IV says that symptoms need to last for only two days for a diagnosis of ASD to be made. Therefore, for the scope of the present study, the authors deemed it necessary to adopt a more up-to-date version of the DSM. Thus, for ASD only, we used DSM-5 criteria for diagnosis. In the DSM-5, ASD is characterized by the onset of a minimum set of symptoms 3 to 30 days after the person has been exposed to a traumatic event. Avoidance, peritraumatic dissociation, intrusive re-experiencing, hyperexcitation, and disruption of normal social/work functioning are the main symptoms listed. After the 30-day mark, diagnosis should be changed to PTSD. ${ }^{2}$

The National Comorbidity Survey Replication ${ }^{3}$ estimates that approximately $6.8 \%$ of the general population will suffer from PTSD at some point in their lives, with the incidence being as high as $9.2 \%$ for individuals in the 45 to 60 age range. Women are more often affected than men, at a ratio of $2: 1$ when adjusted for the relative frequency of trauma between genders. There do not seem to be any studies on the prevalence of ASD in the general population, and prospective studies and systematic reviews differ according to the nature of the event and the context in which it is evaluated. ${ }^{3}$

Various research centers, primarily American, Israeli, and Australian, are noteworthy for undertaking and publishing multi-pronged investigative projects. They range from diagnostic validation, through the search for biomarkers and relevant neuroendocrine findings, to the proposal and testing of different therapeutic strategies for PTSD. ${ }^{1,4}$

Important public health resources may be expended in the post-diagnosis treatment of these individuals, as they often become incapacitated by chronic forms of PTSD or by depression and anxiety. ${ }^{5,6}$ Add to it the prejudices brought on by being away from work and/or the loss of productivity due to treatments, and one can see the relevance of the problem.

In our area, studies on the presence of altered brain-derived neurotrophic factor (BDNF) levels in stress disorders have been appearing. ${ }^{7,8}$ In light of the epidemiological evidence and the findings of the abovementioned studies, the need to better understand ASD is clear. The role of BDNF in learning, motivation, memory, and mood regulation makes it an important protagonist in the investigation of neurobiological factors related to the posttrauma experience. Therefore, the present study sought to assess BDNF levels in patients who have suffered physical trauma and to investigate associations between BDNF levels and ASD subtypes, sociodemographic factors, and mental disorders according to blood collection shift.

\section{Methods}

\section{Sample}

Data were collected at an emergency hospital for physical trauma in Porto Alegre, state of Rio Grande do Sul, southern Brazil. Study participants were patients over 18 years of age, victims of sufficient physical trauma to require hospitalization, and for whom a minimum hospitalization time of 48 hours was recommended by the clinical physician. The studied population was divided according to the shift when blood was collected (morning or afternoon). ASD was diagnosed using DSM-5 criteria. ${ }^{2}$

Patients who refused to participate or who were not able to consent due to their clinical condition were excluded from the study. Patients hospitalized for suicide attempt were also excluded, as they were considered to require a high degree of care related to their psychopathology, which might interfere with this study's results.

The study used a convenience sample of 117 participants. Data collection occurred between July 22 2013 and December 192014.

\section{Instruments}

The Defensive Style Questionnaire (DSQ)

Defense mechanisms were evaluated via this instrument, developed by Bond et al., ${ }^{9}$ subsequently revised by Vaillant et al., ${ }^{10}$ and reorganized by Andrews et al. ${ }^{11}$ as the DSQ-40. The same instrument was also used by Blaya et al., who evaluated defense mechanisms using a Portuguese version of the DSQ-40 and undertook a preliminary study of its adaptation and validation. ${ }^{12}$

\section{Childhood Trauma Questionnaire (CTQ)}

The CTQ was used to evaluate trauma and abuse in childhood. This tool can be applied to adolescents (12 years and older) and adults. The Brazilian Portuguese version of the instrument was reduced to 28 statements related to situations that occurred during childhood, rated using a 5-point Likert scale. Five dimensions of childhood trauma are investigated: physical abuse, emotional abuse, sexual abuse, physical neglect, and emotional neglect. Scores may range from 25 (absence 
of trauma) to 125 (maximum score, indicating that all traumas are fully present). ${ }^{13}$ The original questionnaire forms were bought in the United States to be applied in this study, with permission granted by Pearson Education for the use of assessment products of trauma in childhood.

\section{Mini-International Neuropsychiatric Interview (MINI)}

For the evaluation of psychiatric comorbidities, we used an interview compatible with the DSM-III-R/IV and the 10th edition of the International Statistical Classification of Diseases and Related Health Problems (ICD-10). Evaluation of ASD, however, was made using the five adapted DSM-5 criteria (labeled A through E). Briefly, patients diagnosed with ASD presented dissociative symptoms after exposure to trauma: a concrete episode or threat of death, serious injury, or sexual violence (criterion A). This criterion has four subtypes, $A 1, A 2$, $A 3$, and $A 4$, as follows: directly experienced a traumatic event (A1); witnessed, in person, a traumatic event happening to someone else (A2); learned of a traumatic event, either violent or accidental, that happened to a relative or close friend (A3); and experienced repeated or extreme exposure to adverse details of a traumatic event (A4). While hospitalized after the traumatic event, the individual had at least three of the following dissociative symptoms: subjective feeling of being anaesthetized, being distant, or lacking emotional response; reduced awareness of surroundings; altered sense of reality; depersonalization or dissociative amnesia (criterion B). During hospitalization, the event continued to be relived (criterion C). The subject presented marked aversion to stimuli that might activate memories of the trauma (criterion D). Finally, the individual had heightened symptoms of elevated anxiety or excitability or negative changes in mood and cognition (criterion E). ${ }^{14}$ It is important to note that criterion $A$ was subdivided to enable investigation of the specific types of trauma experienced by ASD patients.

\section{Measurement (blood analysis)}

Four milliliters of blood were drawn from each subject by venipuncture into an anticoagulant-free vacuum tube. The blood was centrifuged at $3000 \mathrm{~g}$ for $10 \mathrm{~min}$ and serum was kept frozen at $-80^{\circ} \mathrm{C}$ until analysis. BDNF serum levels were measured by sandwich enzyme-linked immunosorbent assay (ELISA), using a commercial kit according to the manufacturer's instructions (Millipore, Billerica, MA, USA). Briefly, microtiter plates (96-well flat-bottom) were incubated for 24 hours at $4{ }^{\circ} \mathrm{C}$ with the samples diluted to $1: 75$ in sample diluent and a standard curve ranging from 15 to $1000 \mathrm{pg} / \mathrm{ml}$ of BDNF. Plates were then washed four times with wash buffer followed by the addition of biotinylated mouse anti-human BDNF monoclonal antibody (diluted to $1: 1000$ in sample diluent), which was incubated for 3 hours at room temperature. After washing, a second incubation with streptavidin-horseradish peroxidase conjugate solution (diluted to $1: 1000$ ) for 1 hour at room temperature was carried out. After addition of substrate and stop solutions, the amount of BDNF was determined (absorbance set at $450 \mathrm{~nm}$ ). The standard curve demonstrated a direct relationship between optical density and BDNF concentration.

\section{Statistical analysis}

Categorical variables were described as relative and absolute frequency. Quantitative variables were presented as median and interquartile minimum and maximum, according to the results of the Shapiro-Wild normality test.

The chi-square test was used to compare the sociodemographic characteristics of the groups. The Mann-Whitney $\mathrm{U}$ or Kruskal-Wallis $\mathrm{H}$ tests were used for the independent samples, according to the type of variable and its distribution or due to a small sample size. Spearman's correlation was employed to assess the association between similar variables. The significance level adopted was 0.05 . The analyses were performed in the Statistical Package for the Social Sciences (SPSS) version 18.

\section{Ethical considerations}

The present study is part of a broader research project entitled "Evaluation of acute stress disorder and posttraumatic stress disorder in patients hospitalized for physical trauma," approved by the research ethics committee of Hospital de Clínicas de Porto Alegre, Porto Alegre, state of Rio Grande do Sul (report \#110533/2012). The study was also approved by the research ethics committee of the Municipal Health Department of the Municipality of Porto Alegre (CAAE 02910012.5.3001.5338), and is in accordance with all the ethical recommendations of Resolution 196/96 of the Brazilian National Health Council. The participants and/or their guardians were given all the necessary information, and any doubts related to the study were duly clarified. After this procedure, those who agreed to participate in the study signed an informed consent form. The anonymity of all patients is protected.

\section{Results}

A total of 117 patients admitted to the emergency hospital were evaluated. The reasons for their admission 
were aggression or accident involving physical trauma. The subjects were grouped according to shift of blood collection: 38 subjects from the morning and 79 from the afternoon shift. Following BDNF measurement and questionnaire response analysis, one significant difference was found in the distribution of BDNF levels between the shifts: patients in the afternoon shift showed higher BDNF levels $(U=1906, p=0.018)$ as presented in Table 1.

There were 103 male and 14 female participants. Intergender comparison did not reveal any significant differences $\left(U_{\text {morning }}=74, \mathrm{p}_{\text {morning }}=0.714 ; U_{\text {afternoon }}=\right.$ $\left.358, \mathrm{p}_{\text {afternoon }}=0.507\right)$. The majority had no previous

Table 1 - Differences in brain-derived neurotrophic factor levels according to shift of blood collection

\begin{tabular}{ccc}
\hline Percent & Morning $(\mathbf{n}=\mathbf{3 8})$ & Afternoon $(\mathbf{n}=\mathbf{7 9})$ \\
\hline Min & 0.3 & 1.4 \\
10 & 3.4 & 5.4 \\
20 & 5.2 & 10.9 \\
30 & 9.2 & 19.6 \\
40 & 14.4 & 25.5 \\
50 & 20.2 & 28.6 \\
60 & 23.2 & 33.1 \\
70 & 26.1 & 41.2 \\
80 & 35.5 & 56.1 \\
90 & 56.5 & 69.6 \\
Max & 89.2 & 132.2 \\
\hline
\end{tabular}

Mann-Whitney test $(p=0.018)$. psychiatric history $\left(\mathrm{U}_{\text {morning }}=33, \mathrm{p}_{\text {morning }}=0.291 ; \mathrm{U}_{\text {afternoon }}\right.$ $=605, \mathrm{p}_{\text {afternoon }}=0.352$ ). Participants were subdivided by age into three ranges: $18-30,31-50$ and $51-70$ years old. A difference was observed only between the 1830 group and the 51-70 group for the afternoon shift $\left(U_{\text {morning }}=1107, \mathrm{p}_{\text {morning }}=0.575 ; U_{\text {afternoon }}=7175, \mathrm{p}_{\text {afternoon }}\right.$ $=0.028)$ (Table 2).

The distribution of BDNF levels was compared between the ASD criterion and its subtypes. As seen in Table 3, only seven patients presented a positive diagnosis for general ASD (as opposed to one of its subtypes). Regardless of blood collection shift, no statistical differences were observed $\left(U_{\text {morning }}=82\right.$, $\left.\mathrm{p}_{\text {morning }}=0.983 ; \mathrm{U}_{\text {afternoon }}=92, \mathrm{p}_{\text {afternoon }}=0.640\right)$. Among the negative cases, the mean between the shifts differed by about 10 points. Also, a statistical difference was found between three subtypes of ASD, but only for the afternoon shift. Subjects with ASD subtypes A1 $\left(U_{\text {afternoon }}=892, \mathrm{p}_{\text {afternoon }}=0.013\right), \mathrm{A} 2\left(\mathrm{U}_{\text {afternoon }}=1005\right.$, $\left.\mathrm{p}_{\text {afternoon }}=0.025\right)$, and $\mathrm{A}\left(\mathrm{U}_{\text {afternoon }}=581, \mathrm{p}_{\text {afternoon }}=0.044\right)$ presented a distribution of BDNF lower than that found in subjects without ASD.

Mental disorders were evaluated using the MINI instrument. The most prevalent disorders are presented in Table 4. When BDNF levels were compared according to shift, only substance abuse resulted significant in the afternoon shift $\left(U_{\text {afternoon }}=218, \mathrm{p}_{\text {afternoon }}=0.021\right)$.

The concentration of BDNF was examined in relation to age, number of ASD symptoms, DSQ domains, and scores

Table 2 - Description and comparison of the distribution of brain-derived neurotrophic factor levels according to sociodemographic factors and shift of blood collection

\begin{tabular}{|c|c|c|c|c|c|c|c|c|}
\hline & \multicolumn{4}{|c|}{ Morning } & \multicolumn{4}{|c|}{ Afternoon } \\
\hline & Median [Q1; Q3] & Min-Max & $\mathbf{n}$ & $\mathbf{p}$ & Median [Q1; Q3] & Min-Max & $\mathbf{n}$ & $\mathbf{p}$ \\
\hline \multicolumn{9}{|l|}{ Sex } \\
\hline Male & $20.6[8.4 ; 28.8]$ & $3.2-89.2$ & 33 & 0.714 & $28.5[13.5 ; 42.5]$ & $1.8-132.2$ & 70 & 0.507 \\
\hline Female & $19.5[18.3 ; 24.4]$ & $0.3-26.5$ & 5 & & $38.3[19.7 ; 49.9]$ & $1.4-117.8$ & 9 & \\
\hline \multicolumn{9}{|c|}{ Psychiatric history } \\
\hline Yes & $28.2[14.9 ; 39.0]$ & $14.9-39.0$ & 3 & 0.291 & $27.0[12.2 ; 38.2]$ & $1.4-77.2$ & 17 & 0.352 \\
\hline No & $19.8[6.5 ; 26.5]$ & $0.3-89.2$ & 35 & & $30.7[14.0 ; 46.4]$ & $1.8-132.2$ & 62 & \\
\hline \multicolumn{9}{|c|}{ Age range (years) } \\
\hline $18-30$ & $16.6[10.0 ; 27.3]$ & $6.5-54.6$ & 12 & 0.575 & $20.1^{\mathrm{a}}[8.5 ; 33.1]$ & $1.4-117.8$ & 33 & 0.028 \\
\hline $31-50$ & $23.3[13.8 ; 27.3]$ & $3.2-73.7$ & 16 & & $30.2^{\mathrm{ab}}[19.7 ; 46.4]$ & 1.9-132.2 & 33 & \\
\hline $51-70$ & $10.1[3.5 ; 34.6]$ & $0.3-89.2$ & 10 & & $38.6^{b}[31.2 ; 52.5]$ & 17.2-85.1 & 12 & \\
\hline \multicolumn{9}{|c|}{ Admission reason } \\
\hline Aggression & $10.9[6.5 ; 19.8]$ & $0.3-28.8$ & 9 & 0.135 & $25.6[17.5 ; 41.7]$ & $1.4-132.2$ & 32 & 0.712 \\
\hline Accident & $23.1[8.8 ; 31.4]$ & $3.2-89.2$ & 24 & & $30.7[11.5 ; 50.9]$ & $1.8-117.8$ & 36 & \\
\hline
\end{tabular}

Min-Max = minimum-maximum; $\mathrm{Q}=$ quartile.

Different superscript letters indicate statistical differences. 
in the CTQ domains. Spearman's correlation was calculated to measure the degree to which these variables and BDNF levels were related. Significant correlations were found only for the afternoon shift. Age was the variable with the greatest correlation, showing a moderate degree $\left(r_{\text {afternoon }}=0.34, \mathrm{p}\right.$
$=0.003)$. Among the defense mechanisms, rationalization $\left(r_{\text {afternoon }}=0.22, \mathrm{p}=0.050\right)$ and reaction formation ( $r_{\text {afternoon }}$ $=0.27, \mathrm{p}=0.015)$ presented significance (Table 5 ). These correlations were classified as weak. Trauma did not show significant results.

Table 3 - Comparison of the distribution of brain-derived neurotrophic factor levels according to types of ASD and shift of blood collection

\begin{tabular}{|c|c|c|c|c|c|c|c|c|}
\hline & \multicolumn{4}{|c|}{ Morning } & \multicolumn{4}{|c|}{ Afternoon } \\
\hline & Mean [Q1; Q3] & Min-Max & $\mathbf{n}$ & $\mathbf{p}$ & Mean [Q1; Q3] & Min-Max & $\mathbf{n}$ & $\mathbf{p}$ \\
\hline \multicolumn{9}{|l|}{ ASD A1 } \\
\hline Yes & $21.3[8.4 ; 26.5]$ & $0.3-89.2$ & 30 & 0.830 & $27.0[10.9 ; 38.8]$ & $1.4-117.8$ & 55 & 0.013 \\
\hline No & $16.6[7.4 ; 46.8]$ & $3.4-86.0$ & 8 & & $39.6[23.8 ; 67.0]$ & $3.1-132.2$ & 24 & \\
\hline \multicolumn{9}{|l|}{ ASD A2 } \\
\hline Yes & $20.0[5.3 ; 24.5]$ & $0.3-89.2$ & 22 & 0.408 & $22.8[8.5 ; 38.2]$ & $1.4-132.2$ & 37 & 0.025 \\
\hline No & $21.2[9.2 ; 33.9]$ & $3.4-86.0$ & 16 & & $31.7[21.6 ; 56.2]$ & $3.1-79.4$ & 42 & \\
\hline \multicolumn{9}{|l|}{ ASD A3 } \\
\hline Yes & $20.0[5.8 ; 27.6]$ & $0.3-89.2$ & 20 & 0.640 & $25.7[9.1 ; 41.2]$ & $1.8-85.1$ & 35 & 0.236 \\
\hline No & $21.0[9.2 ; 28.2]$ & $3.4-86.0$ & 18 & & $31.5[18.7 ; 46.1]$ & $1.4-132.2$ & 44 & \\
\hline \multicolumn{9}{|l|}{ ASD A4 } \\
\hline Yes & $22.0[9.2 ; 28.2]$ & $0.3-89.2$ & 15 & 0.800 & $28.9[8.9 ; 45.7]$ & $1.9-85.1$ & 19 & 0.783 \\
\hline No & $19.5[6.5 ; 28.8]$ & $3.2-86.0$ & 23 & & $28.5[13.7 ; 45.0]$ & $1.4-132.2$ & 60 & \\
\hline \multicolumn{9}{|l|}{ ASD A } \\
\hline Yes & $19.8[8.4 ; 25.9]$ & $0.3-89.2$ & 33 & 0.235 & $27.2[13.0 ; 41.8]$ & $1.4-132.2$ & 66 & 0.044 \\
\hline No & $39.0[10.9 ; 54.6]$ & $3.8-86.0$ & 5 & & $41.0[27.1 ; 66.5]$ & $3.1-79.4$ & 13 & \\
\hline \multicolumn{9}{|l|}{ ASD B } \\
\hline Yes & $21.7[8.7 ; 25.4]$ & $0.3-34.6$ & 8 & 0.802 & $19.9[8.5 ; 41.2]$ & $1.4-51.9$ & 10 & 0.288 \\
\hline No & $20.2[8.4 ; 28.8]$ & $3.2-89.2$ & 30 & & $28.9[17.7 ; 46.4]$ & $1.8-132.2$ & 69 & \\
\hline \multicolumn{9}{|l|}{ ASD C } \\
\hline Yes & $20.2[8.4 ; 28.2]$ & $0.3-89.2$ & 38 & - & $28.6[13.5 ; 45.7]$ & $1.4-132.2$ & 79 & - \\
\hline No & & & 0 & & & & 0 & \\
\hline \multicolumn{9}{|l|}{ ASD D } \\
\hline Yes & $24.2[8.7 ; 30.5]$ & $0.3-89.2$ & 16 & 0.460 & $27.5[13.5 ; 49.9]$ & $4.1-132.2$ & 27 & 0.975 \\
\hline No & $19.1[8.4 ; 28.2]$ & $3.2-86.0$ & 22 & & $29.6[13.5 ; 43.0]$ & $1.4-117.8$ & 52 & \\
\hline \multicolumn{9}{|l|}{ ASD E } \\
\hline Yes & $25.4[19.5 ; 28.8]$ & $5.3-89.2$ & 10 & 0.079 & $26.6[9.1 ; 41.0]$ & $1.8-77.2$ & 18 & 0.520 \\
\hline No & $16.6[5.8 ; 25.2]$ & $0.3-86.0$ & 28 & & $30.2[14.0 ; 46.4]$ & $1.4-132.2$ & 61 & \\
\hline \multicolumn{9}{|l|}{ ASD } \\
\hline Positive & $24.0[19.5 ; 24.4]$ & $3.4-26.5$ & 5 & 0.983 & $23.6[5.9 ; 41.2]$ & $5.9-41.2$ & 2 & 0.640 \\
\hline Negative & $19.8[8.4 ; 28.8]$ & $0.3-89.2$ & 33 & & $28.6[14.0 ; 45.7]$ & $1.4-132.2$ & 77 & \\
\hline
\end{tabular}

ASD = acute stress disorder; Min-Max = minimum-maximum; $Q=$ quartile. Mann-Whitney $U$ test.

ASD subdivided by criteria $(A, B, C, D, E)$. 
BDNF in physical trauma - Zatti et al.

Table 4 - Comparison of the distribution of brain-derived neurotrophic factor levels according to mental disorder and shift of blood collection

\begin{tabular}{|c|c|c|c|c|c|c|c|c|}
\hline & \multicolumn{4}{|c|}{ Morning } & \multicolumn{4}{|c|}{ Afternoon } \\
\hline & Mean [Q1; Q3] & Min-Max & $\mathbf{n}$ & $\mathbf{p}$ & Mean $[Q 1 ;$ Q3] & Min-Max & $\mathbf{n}$ & $\mathbf{p}$ \\
\hline \multicolumn{9}{|c|}{ Current depression } \\
\hline No & $21.3[9.3 ; 34.6]$ & $3.2-89.2$ & 26 & 0.370 & $28.8[17.2 ; 46.4]$ & $1.4-132.2$ & 58 & 0.807 \\
\hline Yes & $14.9[5.3 ; 24.5]$ & $0.3-51.1$ & 11 & & $28.4[13.0 ; 41.2]$ & $4.1-73.6$ & 21 & \\
\hline \multicolumn{9}{|c|}{ Current melancholy } \\
\hline No & $20.6[9.3 ; 28.8]$ & $3.2-89.2$ & 29 & 0.461 & $27.3[13.0 ; 43.0]$ & $1.4-132.2$ & 64 & 0.194 \\
\hline Yes & $16.8[5.8 ; 24.2]$ & $0.3-51.1$ & 8 & & $38.0[25.5 ; 51.9]$ & $5.9-73.6$ & 15 & \\
\hline \multicolumn{9}{|c|}{ Past depression } \\
\hline No & $19.8[8.4 ; 28.2]$ & $3.2-89.2$ & 31 & 0.564 & $28.6[17.2 ; 46.4]$ & $1.4-132.2$ & 63 & 0.634 \\
\hline Yes & $25.2[6.5 ; 51.1]$ & $0.3-73.7$ & 6 & & $28.4[8.9 ; 45.7]$ & $4.1-69.3$ & 15 & \\
\hline \multicolumn{9}{|c|}{ Suicide risk } \\
\hline No & $22.0[9.2 ; 28.2]$ & $0.3-89.2$ & 19 & 0.902 & $26.7[14.0 ; 41.8]$ & $1.9-117.8$ & 46 & 0.256 \\
\hline Yes & $18.3[9.3 ; 24.4]$ & $3.5-86.0$ & 9 & & $33.1[21.9 ; 51.9]$ & $1.4-132.2$ & 21 & \\
\hline \multicolumn{9}{|c|}{ Lifetime psychosis } \\
\hline No & $19.8[6.5 ; 25.9]$ & $3.2-86.0$ & 27 & 0.584 & $31.2[19.6 ; 49.9]$ & $1.8-132.2$ & 62 & 0.061 \\
\hline Yes & $22.0[13.7 ; 28.8]$ & $0.3-51.1$ & 10 & & $21.9[8.5 ; 31.4]$ & $1.4-73.2$ & 17 & \\
\hline \multicolumn{9}{|c|}{ Primary agoraphobia } \\
\hline No & $20.6[5.3 ; 28.2]$ & $0.3-89.2$ & 29 & 0.356 & $28.8[17.2 ; 45.7]$ & $1.4-132.2$ & 66 & 0.533 \\
\hline Yes & $21.9[14.3 ; 32.7]$ & $9.3-73.7$ & 8 & & $24.3[11.5 ; 39.6]$ & $5.9-73.6$ & 12 & \\
\hline \multicolumn{9}{|c|}{ Social anxiety disorder } \\
\hline No & $20.6[9.2 ; 28.8]$ & $3.2-89.2$ & 29 & 0.400 & $29.6[14.0 ; 46.4]$ & $1.4-132.2$ & 66 & 0.539 \\
\hline Yes & $18.3[6.5 ; 24.4]$ & $0.3-34.6$ & 9 & & $23.5[13.0 ; 41.2]$ & $5.9-69.6$ & 10 & \\
\hline \multicolumn{9}{|c|}{ Current alcoholism } \\
\hline No & $20.2[9.2 ; 28.2]$ & $0.3-89.2$ & 30 & 0.832 & $31.1[17.2 ; 43.5]$ & $1.8-132.2$ & 53 & 0.900 \\
\hline Yes & $19.5[6.5 ; 24.5]$ & $3.8-34.6$ & 6 & & $27.2[13.0 ; 51.9]$ & $1.4-77.2$ & 26 & \\
\hline \multicolumn{9}{|c|}{ Alcohol abuse } \\
\hline No & $20.2[8.4 ; 28.2]$ & $0.3-89.2$ & 34 & 0.738 & $29.4[13.7 ; 46.1]$ & $1.4-132.2$ & 60 & 0.905 \\
\hline Yes & $14.9[6.5 ; 24.5]$ & $6.5-24.5$ & 3 & & $27.5[13.0 ; 41.8]$ & $5.9-77.2$ & 15 & \\
\hline \multicolumn{9}{|c|}{ Substance dependency } \\
\hline No & $19.5[5.3 ; 28.2]$ & $0.3-89.2$ & 31 & 0.801 & $28.6[13.0 ; 45.7]$ & $1.4-132.2$ & 55 & 0.900 \\
\hline Yes & $20.6[9.2 ; 22.7]$ & $6.5-24.0$ & 5 & & $27.0[13.5 ; 51.9]$ & $1.8-73.2$ & 23 & \\
\hline \multicolumn{9}{|c|}{ Substance abuse } \\
\hline No & $19.7[5.3 ; 28.2]$ & $0.3-89.2$ & 30 & 0.966 & $31.1[19.7 ; 51.9]$ & $1.4-117.8$ & 63 & 0.021 \\
\hline Yes & $15.7[9.3 ; 25.9]$ & $8.4-39.0$ & 6 & & $11.3[8.4 ; 32.3]$ & $1.9-45.7$ & 12 & \\
\hline \multicolumn{9}{|c|}{ Current psychosis } \\
\hline No & $20.6[8.4 ; 28.8]$ & $3.2-89.2$ & 31 & 0.638 & $30.7[15.8 ; 48.2]$ & $1.8-132.2$ & 64 & 0.151 \\
\hline Yes & $18.3[3.8 ; 26.5]$ & $0.3-34.6$ & 7 & & $25.7[8.2 ; 33.1]$ & $1.4-73.2$ & 15 & \\
\hline \multicolumn{9}{|c|}{ Current mental disorder } \\
\hline No & $3.4[3.2 ; 86.0]$ & $3.2-86.0$ & 3 & 0.401 & $38.3[28.6 ; 43.5]$ & $5.4-79.4$ & 5 & 0.469 \\
\hline Yes & $20.6[9.2 ; 28.2]$ & $0.3-89.2$ & 35 & & $27.9[13.5 ; 45.7]$ & $1.4-132.2$ & 74 & \\
\hline
\end{tabular}

Mann-Whitney U test.

242 - Trends Psychiatry Psychother. 2019;41(3) 
Table 5 - Correlations between age, number of ASD symptoms, defense mechanisms, childhood trauma and brain-derived neurotrophic factor levels according to shift of blood collection

\begin{tabular}{|c|c|c|}
\hline & $\begin{array}{c}\text { Morning } \\
r(p)\end{array}$ & $\begin{array}{c}\text { Afternoon } \\
r(\mathrm{p})\end{array}$ \\
\hline Age & $-0.11(0.514)$ & $0.34(0.003)$ \\
\hline \multicolumn{3}{|l|}{ ASD A } \\
\hline Number of symptoms & $-0.10(0.568)$ & $-0.28(0.011)$ \\
\hline \multicolumn{3}{|l|}{ Defensive Style Questionnaire } \\
\hline Mature & $0.15(0.382)$ & $0.19(0.105)$ \\
\hline Anticipation & $0.09(0.603)$ & $0.11(0.325)$ \\
\hline Humor & $0.22(0.190)$ & $0.01(0.927)$ \\
\hline Suppression & $0.18(0.266)$ & $0.07(0.533)$ \\
\hline Sublimation & $-0.05(0.758)$ & $0.17(0.143)$ \\
\hline Rationalization & $0.00(0.980)$ & $0.22(0.050)$ \\
\hline Neurotic & $0.14(0.405)$ & $0.18(0.118)$ \\
\hline Pseudo-altruism & $0.12(0.466)$ & $0.03(0.820)$ \\
\hline Idealization & $0.16(0.336)$ & $0.01(0.926)$ \\
\hline Reaction formation & $0.16(0.334)$ & $0.27(0.015)$ \\
\hline Undoing & $-0.06(0.737)$ & $0.15(0.199)$ \\
\hline Immature & $-0.11(0.521)$ & $-0.02(0.887)$ \\
\hline Projection & $-0.03(0.848)$ & $-0.06(0.585)$ \\
\hline Passive aggression & $-0.21(0.216)$ & $-0.03(0.772)$ \\
\hline Acting out & $-0.29(0.082)$ & $-0.11(0.335)$ \\
\hline Isolation & $0.12(0.472)$ & $-0.14(0.214)$ \\
\hline Devaluation & $-0.27(0.107)$ & $0.02(0.847)$ \\
\hline Autistic fantasy & $-0.16(0.343)$ & $0.19(0.102)$ \\
\hline Denial & $0.11(0.528)$ & $-0.06(0.618)$ \\
\hline Displacement & $-0.07(0.683)$ & $-0.05(0.690)$ \\
\hline Dissociation & $0.05(0.744)$ & $0.00(0.975)$ \\
\hline Splitting & $-0.05(0.766)$ & $-0.02(0.837)$ \\
\hline Somatization & $-0.02(0.922)$ & $0.03(0.779)$ \\
\hline \multicolumn{3}{|c|}{ Childhood Trauma Questionnaire } \\
\hline Emotional abuse score & $0.05(0.794)$ & $-0.15(0.190)$ \\
\hline Physical abuse score & $0.23(0.200)$ & $-0.02(0.884)$ \\
\hline Sexual abuse score & $-0.02(0.926)$ & $-0.15(0.181)$ \\
\hline Emotional neglect score & $-0.12(0.516)$ & $0.09(0.445)$ \\
\hline Physical neglect score & $0.21(0.225)$ & $-0.13(0.271)$ \\
\hline Total score CTQ & $0.16(0.381)$ & $-0.15(0.202)$ \\
\hline
\end{tabular}

ASD = acute stress disorder.

Spearman's correlation.

\section{Discussion}

BDNF is a neurotrophin involved in neuronal growth and survival as well as synaptic plasticity. ${ }^{15}$ It is highly expressed in mammal brains, particularly in the hippocampus, whose function is associated with learning and memory. ${ }^{8,16}$ In this way, BDNF participates in the formation of long-term memory and other cognitive processes and is an important factor to be evaluated in patients who have developed PTSD. ${ }^{17}$

Current studies indicate that factors such as genetics, childhood environment, previous trauma, and psychological and cognitive factors are related to the development of traumatic stress. As it plays a crucial role in neuronal processes, BDNF has been intensely studied in the last decade..$^{1,4,15}$ 
In our literature search, no studies with similar findings were encountered, and we hypothesized that this could be due to the influence of circadian endogenous cortisol variations on BDNF serum production. Authors report that cortisol secretion intensity is higher in humans early in the morning and lower at the end of the day, varying from a maximum of approximately 20 $\mu \mathrm{g} / \mathrm{dl}$ one hour before awakening in the morning to $a$ minimum of about $5 \mu \mathrm{g} / \mathrm{dl}$ around midnight. ${ }^{18}$ A recent study has revealed that glucocorticoid receptors downregulate the expression of BDNF. ${ }^{19}$ In that study, the authors demonstrated that exposure to dexamethasone suppressed the expression of the transcription of BDNF in neuronal cells mediated by glucocorticoid receptors. Thus, based on the hypothesis above, it can be inferred that greater endogenous cortisol serum levels may be associated with diminished BDNF serum expression, leading to the findings of our study (Table 1 ).

With this in mind, studying BDNF levels in patients who have suffered physical trauma, whether they developed ASD or not, has uncovered a significant difference in the distribution of BDNF levels in blood samples collected in morning vs. afternoon shifts, with higher BDNF levels found in the group tested in the afternoon $(U=1906.5, p=0.018)$, as seen in Table 1. Studies show that lowered BDNF expression is implicated in greater sensitivity to stress and an increased response to that stress. ${ }^{20,21}$ Previous results have shown that rats heterozygous for the gene that codes for BDNF were more vulnerable to stress than controls, exhibiting desperation behavior after the stress of mild handling. The BDNF genotype Met/Met has also been associated with a significant proportion of soldiers with traumatic stress. However, only $5.2 \%$ of the total sample presented the Met/Met genotype. In the literature, these findings, together with BDNF polymorphisms, have shown strong association with synaptic plasticity and mood disorders, which have also been associated with greater risk for PTSD.

The literature still indicates that patients with previous traumatic stress, with greater exposure to combat, with a more sustained mild traumatic brain injury during the trauma, and who carry the Met/Met BDNF genotype accounted for $22 \%$ of the variance in posttrauma PTSD scores $\left(r^{2}=0.22, \mathrm{p}<0.001\right){ }^{22}$ In our sample, no correlation was found between previous trauma, development of ASD and changes in BDNF levels.

In one study, low levels of BDNF serum were associated with PTSD, while in another, no relationship was observed with PTSD in victims of urban violence. ${ }^{23}$ However, the Met allele of the BDNF Val66Met polymorphism might be associated with severity of PTSD in war veterans. ${ }^{24}$
Regardless of sample collection shift, no statistical differences were found between the ASD criterion and its subtypes $\left(U_{\text {morning }}=82, \mathrm{p}_{\text {morning }}=0.983 ; U_{\text {afternoon }}=\right.$ 92, $\left.\mathrm{p}_{\text {afternoon }}=0.640\right)$. Among the negative cases, the mean between shifts showed a difference of almost 10 points, which was also observed in a study involving 16 unmedicated emergency patients diagnosed with chronic PTSD due to sexual and/or physical abuse or automobile accidents, in which the authors found similar BDNF serum concentrations for patients with PTSD and patients without the condition (controls) (1.00 0.52 vs. $0.83 \pm 0.44 \mathrm{pg} / \mathrm{ml}, \mathrm{p}=0.39) .{ }^{25}$

A statistical difference was found between three subtypes of ASD, only for the afternoon shift. Subjects with ASD A1 $\left(U_{\text {afternoon }}=892, \mathrm{p}_{\text {afternoon }}=0.013\right), \mathrm{A} 2$ $\left(U_{\text {afternoon }}=1005, \mathrm{p}_{\text {afternoon }}=0.025\right)$, and $\mathrm{A}\left(\mathrm{U}_{\text {afternoon }}=\right.$ $581, \mathrm{p}_{\text {afternoon }}=0.044$ ) presented a lower distribution of BDNF levels when compared to subjects without ASD, which corroborates another study conducted with 23 unmedicated emergency patients diagnosed with PTSD. In that study, diminished BDNF serum concentration was reported for the patients with

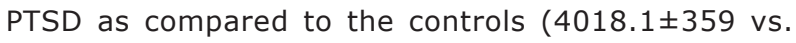
$4886.6 \pm 180 \mathrm{pg} / \mathrm{ml}, \mathrm{p}<0.05) .^{26}$

One study investigated the protective effects of BDNF against the damaging effects of oxidation induced by stress in rats. Rats deficient in BDNF were more susceptible to oxidative damage caused by stress, suggesting that a direct interaction exists between the indicators of oxidative stress and BDNF levels in the brain. ${ }^{27}$

Moreover, the results of the study indicated no significant differences in oxidative stress biomarkers between rats heterozygous for BDNF and wild-gene ones that did not suffer stress.

Parallel to these findings, it has been demonstrated that oxidative stress could increase when BDNF diminished, and also that a reduction in BDNF regulation increased sensitivity to oxidative damage under stressful circumstances. ${ }^{28}$ Additionally, in the same study endogenous defense mechanisms against oxygen free radicals were less effective at suppressing stress-induced oxidative damage in the BDNF efficient group. Taken together, these findings suggest that the neuroprotective effect of BDNF can, in particular, promote the suppression of oxidative impairment.

A growing body of evidence indicates that patients with psychiatric disturbances have altered peripheral BDNF levels, especially those with schizophrenia, depression, and PTSD, ${ }^{29-31}$ which was not visible in our findings. As for psychiatric comorbidities, only substance abuse showed a positive correlation in our sample. Conversely, a previous study conducted 
with a sample of 230 soldiers who participated in combat teams in Iraq and Afghanistan observed that those who developed traumatic stress $(n=41)$ had higher scores for depression ( $d=1.91)$, anxiety ( $d=1.61)$, poor sleep quality $(d=0.92)$, postconcussion symptoms ( $d=2.21)$, alcohol use $(d=$ $0.63)$, traumatic life events $(d=0.42)$, and exposure to combat ( $d=0.91$ ) when compared to those who did not develop traumatic stress. ${ }^{22}$

In the present study, women with PTSD and comorbid depression were 1.52 times more likely to have low BDNF serum concentration $(<25.38 \mathrm{ng} / \mathrm{ml}$ ) than women without these disturbances (odds ratio $[\mathrm{OR}]=1.52 ; 95 \%$ confidence interval $[95 \% \mathrm{CI}] 1.00-$ 2.31). Furthermore, women with isolated depression were 1.83 times more likely to have low BDNF serum concentration, albeit not at a non-significant difference $(\mathrm{OR}=1.83 ; 95 \% \mathrm{CI}$ 0.96-3.46). No association was observed between isolated PTSD and reduced BDNF serum levels $(\mathrm{OR}=1.20 ; 95 \% \mathrm{CI}$ 0.78-1.87).

A case-control study and metanalysis has explored the role of BDNF Val66Met in susceptibility for PTSD among 265 men across veteran hospitals and the Returned and Services League of Australia. Of the total, 158 participants were diagnosed with PTSD, while 107 had also been exposed to trauma but did not develop this comorbidity. The final cohort totaled 257 participants $(\mathrm{PTSD}=151$, no PTSD $=106)$ and underwent chisquare analysis. ${ }^{32}$ Based on earlier studies involving both animal models and human participants, the hypothesis formulated in the current study was that individuals who carry the Met allele would be at greater risk for PTSD than those carrying the Val allele. ${ }^{33}$

One study aimed at assessing the association of BDNF levels with PTSD and depression examined a cohort of 2,928 pregnant women (gestational age > 16 weeks) who received treatment at a pre-natal care clinic in Lima, Peru, and found a decrease in BDNF levels in expectant mothers who presented depression and PTSD, but not in those who has PTSD alone. ${ }^{34}$ Also, no significant differences were observed in BDNF levels in early maternal pregnancy regarding prepartum PTSD (mean of 21.12 vs. $20.67 \mathrm{ng} / \mathrm{ml}, \mathrm{p}=0.21$ ). Mean BDNF serum concentrations were lower among women with comorbid PTSD and depression than in those with none of the comorbidities (mean [interquartile range]: $20.44[16.97,24.30]$ vs. $21.35[17.22,26.01] \mathrm{ng} /$ $\mathrm{ml}, \mathrm{p}=0.06)$, even though the difference was not statistically significant. ${ }^{34}$

In the present study, the following factors were correlated with BDNF levels in 117 patients who were victims of severe physical trauma: collection shift, sociodemographic factors, ASD subtypes, and mental disorders. Seven patients from the sample were also diagnosed with ASD. The group whose blood collection occurred in the afternoon presented significantly greater BDNF values compared to the morning collection. This same group presented lower levels of BDNF when associated with ASD subtypes $A, A 1$, and $A 2$. Regarding mental disorders, only substance abuse was significant in relation to BDNF. Finally, Spearman's correlation showed that rationalization and reactive formation may be associated directly with BDNF levels. It is possible that the low levels of BDNF observed in the morning shift derive from a response to the circadian cortisol cycle, whose action inhibits the expression of serum neurotrophins.

\section{Conclusion}

The levels of BDNF in this study were not sufficiently different to distinguish between patients with ASD (only with its subtypes) and without ASD. We consider this a limitation of the study, as only seven patients met ASD criteria. More studies are necessary to obtain a more precise association of BDNF levels with the development of ASD. Perhaps, when this association is clarified, it will be possible to validate the use of this test in clinical practice for posttraumatic stress.

\section{Acknowledgments}

This study was supported by Fundo de Incentivo à Pesquisa - Hospital de Clínicas de Porto Alegre (FIPEHCPA; grant 110533) and was financed in part by Coordenação de Aperfeiçoamento de Pessoal de Nível Superior (CAPES; Finance Code 001).

The authors are thankful to all the patients who participated in this research, the professionals who collected the data, and the research group who did the work with commitment and dedication.

\section{Disclosure}

No conflicts of interest declared concerning the publication of this article.

\section{References}

1. Bryant RA, Creamer M, O'Donnell M, Forbes D, McFarlane AC, Silove $D$, et al. Acute and chronic posttraumatic stress symptoms in the emergence of posttraumatic stress disorder: a network analysis. JAMA Psychiatry. 2017;74:135-42. 
2. Associação Americana de Psiquiatria. Manual diagnóstico e estatístico de transtornos mentais, $5^{a}$ edição (DSM-5). Porto Alegre: Artmed; 2014

3. Breslau N, Chilcoat HD, Kessler RC, Peterson EL, Lucia VC. Vulnerability to assaultive violence: further specification of the sex difference in post-traumatic stress disorder. Psychol Med. 1999;29:813-21.

4. Birmes P, Brunet A, Carreras D, Ducassé JL, Charlet JP, Lauque $D$, et al. The predictive power of peritraumatic dissociation and acute stress symptoms for posttraumatic stress symptoms: a three-month prospective study. Am J Psychiatry. 2003; 160:1337-9.

5. Ballenger JC, Davidson JRT, Lecrubier $Y$, Nutt DJ, Marshall RD. Consensus statement update on posttraumatic stress disorder from the International Consensus Group on Depression and Anxiety. J Clin Psychiatry. 2004;65:55-62.

6. Breslau N. Epidemiologic studies of trauma, posttraumatic stress disorder, and other psychiatric disorders. Can J Psychiatry. 2002;47:923-9.

7. Jones C, Harvey AG, Brewin CR. The organization and content of trauma memories in survival of road traffic accidents. Behav Res Ther. 2007;45:151-62.

8. Huang EJ, Reichardt LF. Trk receptors: roles in neuronal signal transduction. Annu Rev Biochem. 2013;72:609-42.

9. Bond M, Gardner S, Christian J, Sigal J. Empirical study of selfrated defense styles. Arch Gen Psychiatry. 1983;40:333-8.

10. Vaillant GE, Bond M, Vaillant $\mathrm{CO}$. An empirically validated hierarchy of defense mechanisms. Arch Gen Psychiatry. 1986;43:786-94.

11. Andrews G, Singh M, Bond M. The Defense Style Questionnaire. J Nerv Ment Dis. 1993;181:246-56.

12. Blaya C, Kipper L, Heldt E, Isolan L, Ceitlin LH, Bondb M, et al. Versão em português do Defense Style Questionaire (DSQ-40) para avaliação dos mecanismos de defesa: um estudo preliminar. Braz J Psychiatry. 2004;26:255-8.

13. Grassi-Oliveira R, Stein LM, Pezzi JC. Tradução e validação de conteúdo da versão em português do Childhood Trauma Questionnaire. Rev Saude Publica. 2006;40:249-55.

14. Martins-Monteverde CMS, Padovan T, Juruena MF. Transtornos relacionados a traumas e a estressores. Medicina. 2017;50(Supl.1):37-50.

15. Chen ZY, Patel PD, Sant G, Meng CX, Teng KK, Hempstead BL, et al. Variant brain-derived neurotrophic factor (BDNF) (Met66) alters the intracellular trafficking and activity-dependent secretion of wild-type BDNF in neurosecretory cells and cortical neurons. J Neurosci. 2004;24:4401-11.

16. Lewin GR, Barde YA. Physiology of the neurotrophins. Annu Rev Neurosci. 1990;19:289-317.

17. McEwen C, Chattarji S. Molecular mechanisms of neuroplasticity and pharmacological implications: the example of tianeptine. Eur Neuropsychopharmacol. 2004;14:497-502.

18. Heinrichs $M$, Wagner D, Schoch W, Soravia LM, Hellhammer $\mathrm{DH}$, Ehlert $U$. Predicting posttraumatic stress symptoms from pretraumatic risk factors: a 2-year prospective follow-up study in firefighters. Am J Psychiatry. 2005;162:2276-86.

19. Chen H, Lombés M, Le Menuet D. Glucocoticoid receptor represses brain-derived neurotrophic factor expression in neuron-like cells. Mol Brain. 2017;10:12.

20. Gines S, Seong IS, Fossale E, Ivanova E, Trettel F, Gusella JF, et al. Specific progressive cAMP reduction implicates energy deficit in presymptomatic Huntington's disease knock-in mice. Hum Mol Genet. 2013;12:497-508.
21. Counts SE, Mufson EJ. Noradrenaline activation of neurotrophic pathways protects against neuronal amyloid toxicity. J Neurochem. 2010;113:649-60.

22. Dretsch MN, Williams K, Emmerich T, Crynen G, Ait-Ghezala G, Chaytow $\mathrm{H}$, et al. Brain-derived neurotropic factor polymorphisms, traumatic stress, mild traumatic brain injury, and combat exposure contribute to postdeployment traumatic stress. Brain Behav. 2016;6:e00392.

23. Valente NLM, Vallada $H$, Cordeiro $Q$, Miguita $K$, Bressan RA, Andreoli SB, et al. Candidate-gene approach in posttraumatic stress disorder after urban violence: association analysis of the genes encoding serotonin transporter, dopamine transporter, and BDNF. J Mol Neurosci. 2011;44:59-67.

24. Pivac N, Kozaric-Kovacic D, Grubisic-Ilic M, Nedic G, Rakos I, Nikolac $M$, et al. The association between brain-derived neurotrophic factor Val66Met variants and psychotic symptoms in posttraumatic stress disorder. World J Biol Psychiatry. 2012;13:306-11.

25. Bonne O, Gill JM, Luckenbaugh DA, Collins C, Owens MJ, Alesci S, et al. Corticotropin-releasing factor, interleukin-6, brain-derived neurotrophic factor, insulin-like growth factor-1, and substance $P$ in the cerebrospinal fluid of civilians with posttraumatic stress disorder before and after treatment with paroxetine. J Clin Psychiatry. 2011;72:1124-8.

26. Angelucci F, Ricci V, Gelfo F, Martinotti G, Brunetti M, Sepede $G$, et al. BDNF serum levels in subjects developing or not posttraumatic stress disorder after trauma exposure. Brain Cogn. 2014;84:118-22.

27. Hacioglu G, Senturk A, Ince I, Alver A. Assessment of oxidative stress parameters of brain-derived neurotrophic factor heterozygous mice in acute stress model. Iran J Basic Med Sci. 2016;19:388-93.

28. Hageman I, Andersen HS, Jorgensen MB. Post-traumatic stress disorder: A review of psychobiology and pharmacotherapy. Acta Psychiatr Scand. 2001;104:411-22.

29. Asevedo E, Gadelha A, Noto C, Mansur RB, Zugman A, Belangero $\mathrm{SI}$, et al. Impact of peripheral levels of chemokines. BDNF and oxidative markers on cognition in individuals with schizophrenia. J Psychiatr Res. 2013;47:1376-82.

30. Castren $E$, Rantamaki $T$. The role of BDNF and its receptors in depression and antidepressant drug action: reactivation of developmental plasticity. Dev Neurobiol. 2010;70:289-97.

31. Dell'Osso L, Carmassi C, Del Debbio A, Catena Dell'Osso M, Bianchi $C$, da Pozzo $E$, et al. Brain-derived neurotrophic factor plasma levels in patients suffering from post-traumatic stress disorder. Prog Neuropsychopharmacol Biol Psychiatry. 2009;33:899-902.

32. Bruenig D, Lurie J, Morris CP, Harvey W, Bruce L, Young RM, et al. Case-control study and meta-analysis reveal BDNF Val66Met is a possible risk factor for PTSD. Neural Plast. 2016;2016:6979435.

33. Andero R, Ressler KJ. Fear extinction and BDNF: translating animal models of PTSD to the clinic. Genes Brain Behav. 2012;11:50312.

34. Yang N, Gelaye B, Zhong Q, Rondon MB, Sanchez SE, Williams MA. Serum brain-derived neurotrophic factor (BDNF) concentrations in pregnant women with post-traumatic stress disorder and comorbid depression. Arch Womens Ment Health. 2016; 19:979-86.

Correspondence:

Cleonice Zatti

Rua Ramiro Barcelos, 2400, $2^{\circ}$ andar, Bairro Santana

90035-003 - Porto Alegre, RS - Brazil

E-mail: cleonice.zatti@outlook.com 